\title{
The Ethical Concepts in the Islamic Education Book for Sixth Grade Basic (Comparative Study)
}

\author{
Abdullah Ali Al -Jazi ${ }^{1, *}$ \\ ${ }^{1}$ Department of Curriculum and Teaching, Faculty of Education, Tafila Technical University, Jordan \\ *Correspondence: Department of Curriculum and Teaching, Faculty of Education, Tafila Technical University, Jordan. \\ E-mail: aaljazi@ttu.edu.jo
}

Received: April 7, 2018

Accepted: April 25, 2018 Online Published: May 25, 2018

doi:10.5430/wje.v8n3p131

URL: https://doi.org/10.5430/wje.v8n3p131

\begin{abstract}
The study aimed to compare the book of Islamic Education sixth grade basic in both Jordan and the UAE in the light of the ethical concepts that should be included in the book. To achieve this goal, a list of these ethical concepts was prepared, and according to it, the content of both books has been analyzed. The results showed differences in the availability of these concepts in the books as well as the imbalance in the distribution of these concepts in the books. The results also showed similarities and differences in the content of ethical concepts in both books.
\end{abstract}

Keywords: moral concepts, the book of Islamic education, comparative study

\section{Introduction}

The system of ethics is considered the protective fence of societies and their secure fortification against social spyware and problems that might hinder the progress of these communities. In any society, if its moral system is broken down, this community has been called for disappearance and destruction. The talk about morality is not needless to say, not the luxury of thought; it is to a talk about the survival of a nation or its demise. So it is noted, when reviewing verses of the Holy Quran, that the Holy Quran emphasizes the moral concepts, and this may be evident when the Holy Quran presents the praise of the Prophet Muhammad peace be upon him saying that "And thou on an exalted standard of character" (AlQalam: verse 4)

It is well known that the Holy Quran when the speech is addressed to the Prophet; it 's speech to the whole nation to follow the moral avenue which followed by the Prophet: honesty, trust, the fulfillment of the Covenant, the faithfulness in secret and in public, and sacrifice etc......... This is the high moral system that the Islamic religion has urged. To illustrate the seriousness and status of morality, the Prophet Muhammad (peace and blessings of Allaah be upon him) summed up the purpose of his message to the worlds by saying: " I was sent to uphold and complement ethical values." (Narrated by Ahmad, 2/381, H / 8939).

The Holy Quran mentioned the concept of "moral " twice, the first time in the verse " And thou on an exalted standard of character" (Al- Qalam: verse 4) i.e you are on high virtuous and good character. The second time is in the verse " This is no other than a customary device of the ancients "(Ash- Shuara': verse 137) i.e it is inborn character and the nature of the ancients is to tell lies. So, it is known that morals could be good required and could be hateful and abhorrent. (Al- Saboni 1981), and the Prophet' Hadith: " The most complete of the believers in faith, is the one with the best character among them. And the best of you are those who are best to your women. " (Al-Albani, Sahih Sunan Al-Tirmidhi, Hadeeth no. $1162,1 / 593)$.

Ethics can be defined as: a stable character in the soul. It may be innate or acquired that has effects in the commendable or reprehensible behavior (Al Maidani 1420). It is defined by Abu Hamid al - Ghazali as: a permanent state in the self from which the acts released easily without the need for care or thought (Ghazali, d.t). Ibn Al-Jawzi sees that morality is: the pure will and visible and invisible acts that match with justice, wisdom and interest (Al-Jawzi, 1415).

By reviewing the definition of ethics, the researcher believes that ethics have the status of stability, which guide acts and behaviors performed by persons: Based on what one has of morality, his behavior is a reflection of this morality, whether these behaviors are praiseworthy or blameworthy. The researcher defines ethics as: What stabilizes in the soul from the qualities reflected by the behaviors in real life. 


\subsection{The Need for Ethics}

God created man and deposited wishes, desires and tendencies that attract and push him to good or evil. So there was to be a controller to direct these desires and tendencies in a positive direction so that humans do not fall to the lowest level and elevate them psychologically, mentally and spiritually. So ethics are the controller and the guide and this confirms that ethics are not a luxury plus, received by one and leave it whenever he wants. Ethics are individual, social and an urgent humanitarian necessity. Good morals instill a sense of duty and enables the virtue of self, and this makes the good behavior a self - emission towards truth and goodness and justice. Thus, if the situation of the individual is right, the community is also right. The Prophet Muhammad gave a great position to morals: he made them the aim of his message to the people by saying, " I was sent to uphold and complement ethical values." (Sherqawi, 1990).

\subsection{Sources of Ethics in Islam}

Sources of ethics in Islam are the same sources of Islamic legislation. The Holy Qur'an is the first source of morality, which contains an ethical system that calls for supremacy and eminence. Every verse in it contains an order, to do or forbids it, carry a moral value in its content (Abu Al- Enein, 1988). The second source of ethics is the Prophetic Sunnah because the Prophet Muhammad is the real and behavioral translation of what is stated in the Qur'an of morals. God says to him: " And If you had been rude $\{$ in speech\} and harsh in heart, heartless man, they would have disbanded from about you. " (Al-Imran, 159). The life of the Prophet is an invitation to good morals. The sources of morals in Islam is also juristic deduction (Al- Ijtihad), which means Muslim scholars do their best in order to reach the legitimate rule: it is an important source of ethics because the juristic deduction stems from trustful thinkers and scholars whose goal is to achieve goodness, justice and equality (Murtaja, 2004).

\subsection{Rankings Ethics in Islam}

Ethics levels can be divided from an Islamic perspective into four levels: First: personal ethics that lead to the individual benefit and goodness such as patience to scourge and thanks to the grace. It is linked to the relationship of the individual with God (Al -Asmer, 1997). Second: the social ethics which benefits the community such as cooperation, honoring parents, good neighborliness (Al-Sibai, 1979. Third: human morality which benefits the human whatever. It is based on respecting others' opinions and behaviors (Sabri, 2002). Finally, the universal ethics which benefit all that God created from non-humans like animals and others by investing them for the benefit of all mankind (Al- Hili and Al-Suyuti, 1987).

\subsection{Characteristics of the Moral Growth of the Sixth Grade Students}

At this stage of a child 's life, the moral trends are determined based on the ethics prevailing in the social environment that surrounds him such as family and school. Children, at this stage,are aware of the moral concepts such as truth, justice and honesty. Specifically, here the great role of parents, teachers and educators appears in general as ethical models. Muslims scholars of education such as Al Ghazali, Ibn Miskawayh, Ibn Khaldun considered that childhood is the stage in which ethics are instilled in children; so it is important to have educators as a good example and model for children. Also, it is necessary to take care of ethical education which brings up children according to good principles within the framework of socialization (Hijazi, 2017).

Many studies have focused on the subject of ethics in the curriculum. In one study, Abu Khater (2015) aimed at investigating the level of the ethical values included in the Islamic Education book for the seventh and eighth grades. The study concluded that the book of the Islamic Education for the seventh grade basic included (1304) repetitions of the moral values, where the presence of the value of honesty was great while neglecting the value of reverence of old people. The repetition of moral values in the book of the Islamic Education for the eighth grade is (1359) moral values, where the values of courage, generosity, the connection of the uterus and honesty are the most in the two parts of the book.

Maqqousi, Fatiha (2013) conducted a study that aimed to know the extent books of Islamic education high basic stage included values of love. The researchers used the method of content analysis. The results showed that the repetition of the values of love related to faith and morality in the three books of the Eighth, Ninth and Tenth grades got higher frequencies, then the values of love related to family and school came second and in the third place, the values of love related to life came third.

Al-Khatib's study (2012) aimed to identify the Islamic moral values included in the Arabic language books for the second phase of the basic stage in Jordan. The study concluded that the total number of Arabic language book frequencies reached (2624) distributed over (55) values in four main fields: (dogmatism, worship, materialistic, social). Arabic language books for the sixth grade came first in terms of the frequencies of values in them, then the seventh grade's and finally, the fifth grade's.

Al-Shamlati (2010) also conducted a study aimed at revealing the individual moral values in the Islamic Education books 
for intermediate stage in the Kingdom of Saudi Arabia and the methods of presenting them. The sample of the study consisted of 12 Islamic books of education for intermediate stage in Saudi Arabia. The researcher used analyzing the content of these books. The study tool was presented in (13) lists of individual moral values that are needed in these books. The results showed that the number of individual moral values included in the books of Islamic education prescribed for the middle-aged amounted to (55) individual moral value of the total (68) moral value that should have been available in these books. The results also showed that there is a significant disparity in the presentation of these moral values in these books.

Mansour and Tlafha (2009) conducted a study that aimed to identify the ethical values system which should be included in the Islamic Education book for the basic stage students in Jordan, and the values included in these books. The research sample search consisted of all books(10 books) of the Islamic Education for the basic stage in Jordan. The Results showed that the moral values which should be included in the books of Islamic Education for the basic stage distributed in a hierarchical structure in four fields: the system of the individual moral values, family values, civil values and international values. Also, the results showed that the highest percentage was the field of individual moral values and the lowest proportion was the domain of the international moral values.

After reviewing the previous studies, it is noted that the current study differs from the other studies mentioned above in that it follows the comparative approach. It compares the ethical concepts in the sixth grade book in Jordan with the book of Islamic education for the same grade in the United Arab Emirates.

\section{Problem of Study}

The inclusion of ethical concepts in school textbooks in general and in the primary stage in particular is very important. Providing children at an early age with an ethical system is an important guarantee in creating a generation based on good morals, which is positively reflected on society as a whole since moral concepts are translated into the daily life of society, which helps to form moral societies at all levels: political, economic, social and others, which leads to the prosperity of the community and being free of all kinds of crime.

Accordingly, this study is intended to examine the contents of the ethical concepts in Islamic Education books for the sixth grade in Jordan and in the United Arab Emirates.

\section{Question of the Study}

The study questions are summarized as follows:

- First question: What are the ethical concepts that need to be included in the Islamic Education Book for the sixth grade?

- Second question: What are the moral concepts included in the book of Islamic Education for sixth grade basic in Jordan?

- Third question: What are the ethical concepts included in the book of Islamic Education for the sixth grade in the UAE?

- Fourth question: What are the similarities and differences between the ethical concepts included in the book of Islamic Education for the sixth grade in Jordan and the United Arab Emirates?

\section{Objectives of the Study}

First: - Preparing a list of the most important moral concepts to be included in the book of Islamic education for the sixth grade basic.

Second: - Analysis of the book of Islamic Education in Jordan in light of the list of ethical concepts that have been developed.

Third: - Analysis of the Book of Islamic Education in the UAE in light of the list of ethical concepts that have been developed.

Fourth: - highlighting the similarities and differences in ethical concepts embedded in the book of Islamic education in Jordan and the United Arab Emirates. 


\section{Importance of the Study}

This study is important for the following reasons:

- It examines the ethical concepts of an important stage in the life of students which is the basic stage.

- It is one of the rare studies - according to the researcher - which compares the contents of ethical concepts in the books of Islamic education in two Arab countries.

- It is an important indicator for the curriculum makers since this study is considered an evaluation of the books of Islamic education for the sixth grade basic.

\section{Limitations of the Study}

The study was limited to:

- The book of Islamic Education for the sixth grade in Jordan in its first and second parts.

- The book of Islamic Education for the sixth grade in the United Arab Emirates in its first and second parts.

\section{The Terms of Study(Procedurally)}

- Moral Concepts: It means all words that refer to a set of principles came out by Islam, and asked Muslims to abide by it as truth, sincerity, courage, generosity...etc, and intended in this study a list of ethical concepts that have been prepared for the Purpose of analyzing the book of Islamic education according to it.

- The Book of Islamic Education: a textbook that is issued by the Ministry of Education in both Jordan and the UAE. It contains subjects that are derived from Sharia'a and Islamic law. What is intended to study here is the book of Islamic Education for sixth grade basic in Jordan, which has been taught since 2015, and the book of Islamic education for the sixth grade in the United Arab Emirates, which has been taught since ` 2017.

- Sixth Grade: A middle school stage between the lower basic stage and the higher basic stage.

- Comparative study: Methodology in scientific research on which comparisons are made between two parallels to highlight similarities and differences.

\section{Methodology of the Study}

To achieve the objectives of the study, three approaches were followed:

First: The philosophical approach in tracing the various sources to extract the most important moral concepts that should be included in the books of Islamic education for the sixth grade.

Second: The analytical descriptive approach (analysis of content), which refers to the description of the phenomenon as it is, and analytical by tracking the topics of Islamic education books and extracting the ethical concepts thereof.

Third: The comparative method to compare the ethical concepts in the book of Islamic Education for sixth grade basic in Jordan, and ethical concepts in the book of Islamic Education for sixth grade basic in the UAE.

\section{Procedures of the Study}

First: The population of study: The population of the study is the book of Islamic education in its first and second parts for sixth grade in Jordan, which the Ministry of Education in Jordan has to teach since 2015, and the Islamic education book in its first and second parts for the sixth grade in the United Arab Emirates, which the Ministry of Education in the UAE has decided to teach since 2017.

Second: The sample of the study: it is the same as the population of the study. Table (1) shows that:

Table 1. Books of Islamic Education for the Sixth Grade in Jordan and the United Arab Emirates

\begin{tabular}{ccc}
\hline Book name & Country & Date of teaching \\
\hline Islamic education & Jordan & 2015 \\
Islamic Education (Student Book) & Arab Emirates & 2017 \\
\hline
\end{tabular}


Third: Tools of the study: This is an analysis form composed of the most prominent ethical concepts that should be included in the book of Islamic education for the sixth grade basic. This tool was built by the following steps:

- Through an open question about the most important moral concepts that should be included in the book of Islamic education for the sixth grade basic. This question has been addressed to a number of educators and professors in the disciplines of education and the Shari'a(Islamic Religion). In addition, the researcher tends to refer to a set of research and studies which were carried out on the topic to benefit from what he has reached in this regard.

- Validity of the tool: The so-called virtual validity of the tool, which was presented to a group of arbitrators specialized in this regard. Some of the views of these arbitrators have been taken into consideration by the deletion of some concepts or the inclusion of others.

- The stability of the tool: To ensure the stability of the tool, the researcher analyzed a sample of the books of Islamic education in Jordan and UAE according to the list of analysis reached as a study tool. Another analyst analyzed the same sample of books also according to the list of analysis. The other analyst has been trained on how to analyze. Then Holsti equation was used to extract the coefficient of stability, which states that: (Ta'imah, 1987)

- Stability $=\frac{(\text { number of times of agreement between analysts) }}{\text { Number of times of agreement }+ \text { number of times of disagreement }} \times 100 \%$

- Stability $=\frac{39}{39+8} \times 100 \%=83 \%($ which is a good stability ratio. $)$

Fourth: the unit of analysis: it was the direct word which expressed the concept, because it is the most obvious in reference to the moral concept, and according to it, frequencies and percentages were counted and calculated.

Fifth: - Category of analysis: it is all the ethical concepts contained in the study tool.

Sixth: Method of analysis

- Preparation of the ethical concepts that should be included in the book of Islamic education for the sixth grade basic.

- Verification of validity and stability.

- identifying all the ethical concepts contained in the book of Islamic education in the sixth grade in Jordan and in the UAE.

- Extracting duplicates, percentages and rank of ethical concepts.

- Comment on the results.

Seventh: Statistics

Duplicates, percentages, and rank were used because they match with the study questions.

\section{The Results and Discussion}

First: - Results related to the first question, which is " What are the ethical concepts that need to be included in the Islamic Education Book for the sixth grade? " The question was answered through the introduction of this subject to the experienced and specialized researchers in this field. Also, a review of related literature and studies concerning the topic was made. The results indicated that the most important ethical concepts that should be included in the Islamic Education Book for the sixth grade are:

(Honest, truthfulness, love, good neighborliness, generosity, respect, kindness, benevolence, amnesty, compassion, courage, selflessness, cooperation, modesty, justice, tolerance, apology, patience).

These concepts constitute an important moral system for the students of the basic stage because they work on the character of the student, so that the final outcome of the students is a positive personality with a good influence in the community.

Second: - Results related to the second question, which read: " What are the ethical concepts included in the book of Islamic Education for the sixth grade in Jordan?

To answer this question, the topics of the Islamic education book for the sixth grade basic in Jordan were analyzed in light of the ethical concepts list described above, and 
Table (2) shows the result:

Table 2. Frequencies and Percentages and Rank of the Concepts in the Islamic Ethical Education Book for Sixth - Grade Basic in Jordan

\begin{tabular}{ccccc}
\hline Number & Ethical Concepts & Duplicates & Percentage & Rank \\
\hline 1 & Justice & 52 & $22.90 \%$ & 1 \\
2 & Truthfulness & 48 & $21.14 \%$ & 2 \\
3 & Compassion & 18 & $7.92 \%$ & 3 \\
4 & Patience & 16 & $7.04 \%$ & 4 \\
5 & Amnesty & 15 & $6.60 \%$ & 5 \\
6 & Honesty & 14 & $6.16 \%$ & 6 \\
7 & Love & 14 & $6.16 \%$ & 6 \\
8 & Cooperation & 12 & $5.28 \%$ & 7 \\
9 & Generosity & 9 & $3.96 \%$ & 8 \\
10 & Kindness & 8 & $3.52 \%$ & 9 \\
11 & Courage & 6 & $2.64 \%$ & 10 \\
12 & Selflessness & 5 & $2.20 \%$ & 11 \\
13 & Respect & 4 & $1.76 \%$ & 12 \\
14 & Benevolence & 2 & $0.88 \%$ & 13 \\
15 & Good neighborly & 1 & $0.44 \%$ & 14 \\
16 & Modesty & 1 & $0.44 \%$ & 14 \\
17 & Tolerance & 1 & $0.44 \%$ & 14 \\
18 & Apology & 1 & $0.44 \%$ & 14 \\
& Total & 227 & Almost 100\% & \\
\hline
\end{tabular}

The above table shows that the moral concepts in the book of Islamic education for the sixth grade in Jordan are all available, but in varying degrees: some ethical concepts are present in a great way (justice, honesty ), while some concepts are almost nonexistent (such as modesty, good neighborliness, apology), and moral concepts with moderate presence such as (compassion, patience, amnesty, honesty, love) and relatively available such as (Cooperation, generosity, kindness, courage, benevolence, respect).

It is noted that justice came in the first order followed by truthfulness, then mercy, and patience came in the fourth order. Perhaps the focus on these moral concepts than others due to their importance from the point of view of the authors of the book of Islamic education: justice is very important in all aspects of life, and without it the balance of society breaks down. And honesty is the basis of confidence in the treatment of people with each other, and perhaps what gives beauty to life is compassion among people. As for patience, it is a great character as life must be permeated by some pitfalls and need patience to overcome.

Question 3: What are the ethical concepts included in the book of Islamic Education for the sixth grade in the UAE? To answer this question, the topics of the Islamic Education Book for the sixth grade were analyzed in the United Arab Emirates. The frequency, percentages and rank of ethical concepts were extracted. Table (3) shows the result: 
Table 3. Frequency, Percentage and Rank of Ethical Concepts in the Book of Islamic Education for the sixth Grade in the United Arab Emirates

\begin{tabular}{ccccc}
\hline Number & Ethical Concepts & Duplicates & percentage & Rank \\
\hline 1 & Justice & 9 & $3.61 \%$ & 8 \\
2 & Truthfulness & 12 & $4.81 \%$ & 7 \\
3 & Compassion & 44 & $17.67 \%$ & 3 \\
4 & Patience & 53 & $21.28 \%$ & 2 \\
5 & Amnesty & 25 & $10.04 \%$ & 4 \\
6 & Honesty & 1 & $0.40 \%$ & 11 \\
7 & Love & 16 & $6.42 \%$ & 6 \\
8 & Cooperation & 59 & $23.69 \%$ & 1 \\
9 & Generosity & 1 & $0.40 \%$ & 11 \\
10 & Kindness & 7 & $2.81 \%$ & 9 \\
11 & Courage & nothing & $0.00 \%$ & --- \\
12 & Selflessness & 2 & $0.80 \%$ & 10 \\
13 & Respect & 18 & $7.22 \%$ & 5 \\
14 & Benevolence & nothing & $0.00 \%$ & ---- \\
15 & good neighborly & nothing & $0.00 \%$ & ---- \\
16 & Modesty & nothing & $0.00 \%$ & ---- \\
17 & Tolerance & 2 & $0.80 \%$ & 10 \\
18 & Apology & nothing & $0.00 \%$ & ----- \\
& Total & 249 & Almost $100 \%$ & \\
\hline
\end{tabular}

It is clear from the above table that some moral concepts such are clear such as: cooperation, patience and compassion. There are moral concepts that are not available such as courage, benevolence, good neighborliness, modesty and apology respect, and there are ethical concepts that are relatively weak available such as: tolerance, selflessness, generosity, honesty. This shows that there is a clear problem in the availability of ethical concepts, and perhaps it is clear that the reason is that the ethical concepts that were not available here were included in the books of Islamic education in other stages of study. In all cases, the authors of the book of Islamic education should include these ethical concepts in the book of Islamic Education for the sixth grade, since their repetition is indicative of its necessity and importance and become increasingly entrenched in the personality of the learner.

It is noted from the above table that ethical concepts (cooperation, patience, compassion, amnesty) are in an advanced order than other ethical concepts, and may be attributed to the fact that these concepts focus more than others on the coherence of the community structure and emphasize its unity through cooperation and compassion and patience on the calamities and amnesty when estimated.

Question four: What are the similarities and differences between the moral concepts included in the book of Islamic Education for the sixth grade in Jordan and the United Arab Emirates?

Given the two tables above (2) and (3), it is clear that the nature of the agreement lies in the availability of a set of common ethical concepts in both books: justice, truthfulness, honesty, compassion, patience, amnesty, love, cooperation, generosity, kindness, benevolence, respect, tolerance, but the differences between the two books lies in the moral concepts in the book of Islamic education in Jordan which are all available, while some of the ethical concepts are not available in the book of Islamic education in the UAE. The concept of justice came in the first order in the book of Islamic Education in Jordan, while the concept of cooperation came first among the ethical concepts in Islamic Education in the UAE. The two books are similar in the moral concepts (patience, compassion) in the list of ethical concepts contained in both books. 


\section{Recommendations}

Based on the above results, the study recommends the following:

- The need to include all important moral concepts in the book of Islamic education for the sixth grade basic.

- To include the inclusion of ethical concepts in a balanced way in the book of Islamic Education for the sixth grade.

- Conducting more comparative studies on ethical concepts in the books of Islamic education in different stages of study.

\section{References}

Abu Khater Ashraf Marzouk. (2009). The Level of The Inclusion of Ethical Concepts in Islamic Education Books from The Palestinian Curriculum for Seventh and Eighth Grades A research to fulfill the Requirements of BSC Degree from College Education, Al-Quds Open University, Palestine.

Al - Haly, Jalal \& Al-Souti, Jalal. (1987). Tafseer Al- Jalalin. Damascus: Dar Al-Fajr Al-Islami.

Al - Sharqawi, Muhammad Abdullah. (1990). Moral Thought: Comparative Study (1st Ed.). Beirut: Dar al-Jil.

Al- Asmar, Ahmad. (1997). Philosophy of Education in Islam Affiliation and Promotion. Jordan: Dar Al-Furqan for Publishing and Distribution.

Al- Jawzi, Ibn al -Qayyim Muhammad Ibn Abi Bakr. (1415). The Statement In The Sciences Of The Holy Quran (1st ed.). Beirut: Dar al-Kitab al-Arabi.

AL- Maidani, Abdulrahman Hassan. (1420). Islamic Morals and Its Roots (5th Ed.). Damascus: Dar Al-Galem.

Al-Maqusi, Yasin Ali \& Fatihah, Mahmood Ali. (2013). The Extent Of The Islamic Education Books In The Basic Stage In Jordan For The Values Of Love (Analytical Study). Journal of the Islamic University for Educational and Psychological Studies, 21(4), 129-155.

Al-Shamlti, Omar Abdulqadir. (2010). Individual Ethical Values Included in the Books of Islamic Education in The Middle Stage in Saudi Arabia And the Methods of Presentation of Them. Journal of the Faculty of Education Zagazig, 68, 59-95.

Ghazali, Abu Hamid Muhammad (DT). Revival of the Sciences of Religion (3rd Ed.). Beirut: Dar Al-Qalam.

Hajazi, Maha Nabil. (2017). Characteristics of Primary School Students and How to Consider Them. Retrieved from https://sites.google.com/site/filrachievmentmaha

Huda, Mansour \& Talafah. (2009). The System Of The Moral Values Included In The Books Of Islamic Eduction For The Basic Stage In Jordan. Studies of Educational Sciences, 36(1).

Khatib, Mohamed Ibrahim (2012) Islamic Moral Values Included in the Arabic Language Books Scheduled for the Second Stage of the Basic Stage in Jordan. The Saudi Society for Educational and Psychological Sciences. Retrieved from http://platform.almanhal.com

Mrtjy, Ahed Mahmoud. (2004). The Extent of The Practice of Secondary School Students to The Ethical Values From The Point Of View Of Their Teachers In The Province Of Gaza. Master Geller published, the University of Al - Azhar, Gaza.

Sabouni, Mohamed Ali. (1981). Safwa Tafaseer. Vol.2, Beirut: House of the Holy Quran.

Sabri, Nayla. (2002). The vision of the Light of the Qur'an. Vol IX, Jerusalem: Press of Jerusalem.

Sbai, Mustafa. (1979). Our Social Ethics (4th ed.). Lebanon: Islamic office.

Taima, Rushdie (1987). Content Analysis in Human Sciences: Concept - Bases - Uses. Cairo: Arab Thought House. 